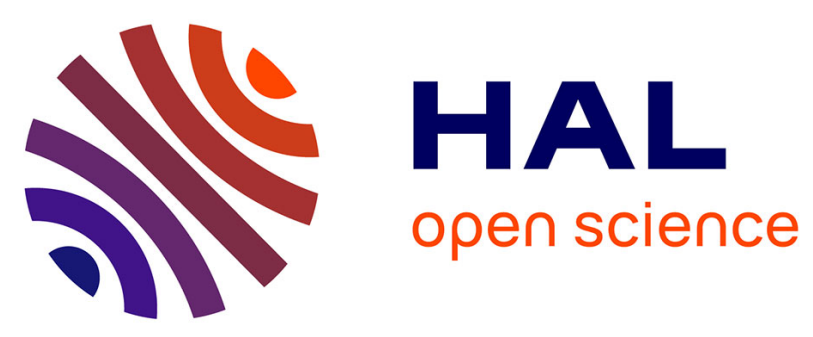

\title{
Hydro-climate changes over southwestern Arabia and the Horn of Africa during the last glacial-interglacial transition: A pollen record from the Gulf of Aden
} Wiem Fersi, Anne-Marie Lézine, Franck Bassinot

\section{- To cite this version:}

Wiem Fersi, Anne-Marie Lézine, Franck Bassinot. Hydro-climate changes over southwestern Arabia and the Horn of Africa during the last glacial-interglacial transition: A pollen record from the Gulf of Aden. Review of Palaeobotany and Palynology, 2016, 233, pp.176-185. 10.1016/j.revpalbo.2016.04.002 . hal-01318345

\section{HAL Id: hal-01318345 \\ https://hal.sorbonne-universite.fr/hal-01318345}

Submitted on 19 May 2016

HAL is a multi-disciplinary open access archive for the deposit and dissemination of scientific research documents, whether they are published or not. The documents may come from teaching and research institutions in France or abroad, or from public or private research centers.
L'archive ouverte pluridisciplinaire HAL, est destinée au dépôt et à la diffusion de documents scientifiques de niveau recherche, publiés ou non, émanant des établissements d'enseignement et de recherche français ou étrangers, des laboratoires publics ou privés. 


\section{Hydro-climate changes over Southwestern Arabia and the Horn of Africa} during the last Glacial-Interglacial transition: A pollen record from the

\section{Gulf of Aden}

WiemFersi $^{1,2}$, Anne-Marie Lézine ${ }^{2}$ and Franck Bassinot ${ }^{1}$

${ }^{1}$ Laboratoire des Sciences du Climat et de l'Environnement/IPSL, CEA-CNRS-UVSQ UMR8212, CE Saclay, l'Orme des Merisiers, 91191 Gif-sur-Yvette Cedex, France

${ }^{2}$ Sorbonne Universités, UPMC-Univ Paris 06, CNRS-IRD-MNHN, LOCEAN/IPSL laboratory, 4 place Jussieu, 75005 Paris, France

\section{Abstract}

We studied a marine sedimentary section deposited at a high sedimentation rate in the Gulf of Aden (core MD92-1002) to document environmental and hydrological changes since the end of the last glacial periodand better understand the onset and decay of the Holocene Humid Period (HHP). Pollen analysis reveals that the period from the LGM to $13.5 \mathrm{ka}$ was hyper arid with sparse vegetation cover characterized by xerophitic taxa from the Saharo-Sindian phytogeographical region. Humidity increased since 14.9 ka to reach a maximumbetween $\sim 9$ and $7.5 \mathrm{ka}$, as revealed by peak abundances of the tropical mangrove Rhizophora and high values of a pollen-based humidity index.The HHP ended up gradually, starting to decline as soon as $7.5 \mathrm{ka}$ and collapsing definitively at $4 \mathrm{ka}$. This decline is characterized by the appearance of Mediterranean taxa and the return of arid conditions, comparable to that of today. Comparison of our pollen record with three speleothem records from the Arabian Peninsula makes it possible to reconstruct a northward and westward shift of the Inter-Tropical Convergence Zone at the onset of the HHP.

wiem.fersi@1sce.ipsl.fr ; anne-marie.lezine@locean-ipsl.upmc.fr; franck.bassinot@1sce.ipsl.fr 


\section{Key words}

Arabia;Horn of Africa;Gulf of Aden;Pollen; Holocene Humid Period;Monsoon.

\section{Introduction}

The tropical deserts of Northern Africa and the Arabian Peninsula constitute one of the driest environments onEarth. These areas have experiencedhigh amplitude climatic variations during the late Quaternary with one of the most spectacular arid-humid shift during the early Holocene leading to the development of freshwater lakes over Arabia and the Horn of Africa (Gasse, 1977; Gasse and Fontes, 1989; Lézine et al., 2011; 2014 and reference therein). It is nowwell understood since e.g., COHMAP (1988) that this large-scale climate change resulted from the orbitally-induced increase in summer solar radiation, which was responsible for increased thermal contrast between land and sea and thus produced strong summer monsoon rainfalls over regions that are arid today and resulted in significant changes in atmospheric dynamics and wind patterns(e.g. Kutzbach and Street-Perrot, 1985; Prell and Kutzbach, 1987; Clemens and Prell, 1990; Liu et al., 2003; Barker et al., 2004; Marzin and Braconnot, 2009; Bassinot et al., 2011; Lézine et al., 2011). Although orbitally-driven summer insolation variations took place gradually, several paleoclimatic records have provided evidence ofabrupt changesat the onset or termination of the Holocene Humid Period (HHP, 15-5 ka BP), which could be resulting either (i) from the remote influence of centennial-scale, highlatitude instabilities on tropical climate dynamics, in particular through latitudinal shifts of the Inter-Tropical Convergence Zone (ITCZ; e.g. Peterson et al., 2000; Haug et al.,2001), or (ii) from internal climate feedbacks and/or climate-biosphere feedbacks (Renssen et al., 2006; Castañeda et al., 2009).Reconstructing the precise spatio-temporal evolution leading to and from the HHP is mandatory to fully understand the mechanisms at play. Yet, there are significant discrepancies between paleoclimate reconstructions of humidity/aridity changes 
across tropical Africa and the Arabian area since the last glacial period, and the timing and structure of the Holocene humid period onset and termination arestill debated (e.g., deMenocal et al., 2000; Kröpelin et al., 2008).

Tierney and deMenocal (2013), for instance, claimed that the onset and termination wereboth abrupt and generallysynchronous all over East Africa from Lake Tanganyika to the South $\left(6^{\circ} \mathrm{S}-15.76 \mathrm{ka}\right)$ to the Gulf of Aden to the North $\left(12^{\circ} \mathrm{N}-14.68 \mathrm{ka}\right)$, illustrating the strong teleconnection that exists between equatorial/subequatorial and high latitudes of the northern hemisphere as already noted by Gasse et al. (2008).However, in the Chew Bahir basin (southern Ethiopia), sedimentological changes derived from high-resolution XRF-core scanning show that the HHP started earlier, at $19 \mathrm{ka}$, and was characterized by two abrupt, step-like increases in humidity that were coeval with (i) the onset of B/A and (ii) the termination of the YD, respectively (Foerster et al., 2012). But the end of the HHP, on the other hand, was rather progressive (Foerster et al, 2012), suggesting a climatic transition that was gradual, confirming what has been deduced from lacustrine sediments in the Sahara desert (Kröpelin et al., 2008).

Lézine et al. (2014) stressed out regional differences in the dynamics of HHP onset and termination based on a comprehensive dataset of nearly 2147 well-dated hydrological records (lacustrine, palustrine, spring and fluvial, arid). They showed that the Arabian Peninsula and the Horn of Africa have experienced a significantly shorter humid period compared to northern Africa even though the optimum of the Holocene humiditywas contemporaneous. Lézine et al. (2014) also concluded that the onset and termination of the HHPwereprogressive in western Africa, but more abrupt in eastern Africa (Sudan, Egypt), and possibly also over the Horn of Africa and Arabia, although the low amount ofwell-dated hydrological data in these two regions made it more difficult to conclude.

In order to provide additional pieces of evidence to help deciphering properly the set of events 
that lead to the onset and termination of the Holocene humid period, we studied pollen assemblages from marine core MD92-1002 recovered in the Gulf of Adento reconstruct main environmental and climate changes, which occurred at the junction between the Horn of Africa and Southwestern Arabia. The exceptionallyhigh sedimentation rates, which characterize this record $(\sim 45 \mathrm{~cm} / \mathrm{ka})$, enable us to cope in details with the structure and timing of the last deglaciation. Comparison with earlier studies from marine cores (Core P178-15P Tierney and deMenocal, 2013, and core KL74 -Sirocko et al., 1993) and continental archives from both lacustrine deposits (Lézine et al., 2014) and speleothems (Neff et al., 2001; Fleitmann et al., 2007; Shakun et al., 2007; Van Rampelbergh et al., 2013) make it possible toexamine the relative influence of southern (African) or northern (Arabian) origin and reconstruct the spatial and temporal changes of summer monsoon, with a special emphasis on the Holocene humid period and environmental changes across the last deglaciation.

\section{Modern environmental setting}

\subsection{Regional climatology}

The hydrology over the Southern Arabian Peninsula and the Horn of Africa ismodulated by the seasonal migration of theITCZ.During the boreal summer (June-September), the South Asian landmass is warmer than the Indian Ocean; a low-pressure gradient develops resulting in SW-NE winds blowing over the Arabian Sea and transferring humid air masses to the surrounding continents as part of the general northward shift of the ITCZ. This air flux reaches the Horn of Africa and follows the Southern Arabian coasts where precipitations occur. During the boreal winter (November-February), the continents cool down more strongly than the adjacent ocean. Pressure gradients reverse, which in turn causes a reversal of atmospheric wind circulation over the Arabian Sea with major wind blowing NE-SW 
direction, in association with the shift of the ITCZ to the South. As a result, arid conditions settle over the Arabian Peninsula while, the Mediterranean depressions penetrate southward through the Red Sea and the Persian Gulf (Figure 1).

Because ITCZ does not extend far north over the Arabian Peninsula during the summer season, monsoonal precipitations remain largely confined to restricted areas along the southwestern part of the peninsula and the regional climate is dry with high annual temperature $\left(26-36^{\circ} \mathrm{C}\right)$ and low rainfall (less than $100 /$ year).

\subsection{The Gulf of Aden}

The Gulf of Aden is located in the Arabian Sea between Yemen, on the southern coast of the Arabian Peninsula, and Somalia in the Horn of Africa (Figure 2). It is connected to the Red Sea through the Bab-el-Mandeb strait ( 20 miles wide and 140 m deep; Sheppard, 2000).Because of the arid surrounding environments, the terrigeneous material that feeds marine sedimentation is mainly eolian, windborne dust particles originating from Northern Africa and/or the Arabian Peninsula (Sirocko et al., 1993; Leuschner and Sirocko, 2000; Sirocko et al., 2000; Stein et al., 2007).The Gulf of Adenis bathed by bottom waters with low oxygen content, which result from the strong export productivity in the Arabian Sea and its insufficient ventilation (van Weering et al., 1997). The low oxygen content of bottom water results in the good preservation organic carbon, and the overall high abundance of pyrite in sediments (Bouilloux et al., 2013a,b).

\subsection{Vegetation}

The regional vegetation belongs to four distinct phytogeographical domains (Figure 2; Ghazanfar and Fisher,1998; Wood, 1997; Zohary,1973; White, 1983). The Saharo-Sindian domain in the Arabian desertsis characterized by scarce, herbaceouspopulations mainly 
composed of Artemisia monosperma, Cornulaca arabica, Calligonum comosum, Cyperus conglomeratus, Tribulus arabicus, Plantago ciliate and Dipterygium glaucum. The IranoTuranian domain to the North of the Arabian Peninsula at the edge of the Mediterranean region and to the Northeast, is characterized by Artemisia herba-alba associated with Centaurea sp., Ephedra sp. and various Asteraceae. The Somalia-Masai domain to the SouthWest of the Arabian Peninsula and the Horn of Africa is composed of semi-arid grasslands and deciduous woodland and scrubs with Acacia sp., Commiphora sp. associated with various Euphorbiaceae, Cadaba longifolia and Dodonea viscosa.

The Afromontane domain, between 1000 to $3000 \mathrm{~m}$ above sea level in the Ethiopian plateaus to the South and the high mountains of Yemen and Oman to the North and Northeast, is composed of evergreen forests. This domain is extremely reduced in the Arabian highlands with only Olea europea and Juniperus procera among the most characteristic species. In East Africa, the Afromontane vegetation is more diverse, including, among others, Podocarpus latifolius, Olea capensis, Juniperus procera and Hagenia abyssinica.

High salinity and arid to hyper-arid climate conditions strongly limit littoral mangrove occurrence in the Red Sea and the Gulf of Aden. Mangrovesareonly found as restricted communities in sheltered embayment. They are mostly monospecific with Avicennia marina, which is adapted tovery salty, dry and evaporate conditions. Rhizophora mucronata, which is well adapted to tropical climates, requires wetter conditionsand freshwater input. It is extremely rare in the Gulf of Aden and is onlyrestricted to few areas of Djibouti, Eritrea and the Red Sea coast of Yemen (Spalding, 2010; PERSGA/ALECSO, 2004).

\section{Material and Methods}

2.1 Core MD92-1002 
Core MD92-1002was recovered in the Gulf of Aden, near the Bab-el-Mandeb sill, at $12^{\circ} 01^{\prime} 32 \mathrm{~N}-44^{\circ} 19^{\prime} 02 \mathrm{E}$ (1327 m water depth) during the MD73 RedSea cruise of R/V Marion Dufresne in 1992. The sedimentary column recovered in core MD92-1002 is $9.5 \mathrm{~m}$ long. The sediment is relatively homogeneous, consisting in greenish clay-dominated sediments with pyrite. Stratigraphic control of core MD92-1002 is provided by a $\delta^{18} \mathrm{O}$ recordobtained from the planktonic foraminifera Globigerinoides ruber picked at a $\sim 5 \mathrm{~cm}$ resolution (Ouahdi, 1997; Bouilloux et al., 2013a,b).The $\delta^{18} \mathrm{O}$ stratigraphy revealed that core MD92-1002 reaches the Last Glacial Maximum (LGM)with expanded Holocene ( 400 cmthick) and deglacial ( 350 cm-thick) sections (Figure 3, left).

Initial samples used for isotopic analyses (Ouahdi, 1997) could not be located. In order to control precisely the fine structure of the last deglaciation and be able to look in details at potential phase relationship between pollen variations and isotopic changes, additional $\delta^{18}$ Oanalysesof $G$. ruber (white, sensus stricto morphotype) have been performed on the exact same samples used for our palynological analyses. For these new isotopic data, fine material inside the shells was removed by ultra-sonification during 15 seconds in methanol. Stable oxygen isotopic compositions were measured at LSCE on dual-inlet gas mass spectrometers. All results are expressed as $\delta^{18}$ Oversus V-PDB (in \%o) with respect to NBS 19 and NBS 18 standards. The internal analytical reproducibility determined from replicate measurements of a carbonate standard is $+/-0.05 \%$. Both isotopic records are displayed in Figure 3 (left). The original record (Ouahdi, 1997; Figure 3-left, dotted line) showed a marked positive peak in the deglaciation, at about $11 \mathrm{ka} \mathrm{BP,} \mathrm{which} \mathrm{had} \mathrm{been} \mathrm{interpreted} \mathrm{as} \mathrm{associated} \mathrm{to} \mathrm{the} \mathrm{Younger}$ Dryas. No such a sub-structure isobserved in the new record (Figure 3-left, plain line).

\subsection{Age model}

The chronology of Core MD92-1002 is based on 10 AMS ${ }^{14} \mathrm{C}$ dates obtained on shells from 
shallow dwelling planktonic foraminifera G. ruber and Globigerinoides sacculifer

(Table1).Measurements were performed at the Laboratoire de Mesures Carbone 14 (LMC14, Saclay, France). ${ }^{14} \mathrm{C}$ dates were converted to calendar ages usingthe OxCal 4.2 software (Oxford Radiocarbon Accelerator Unit; Bronk and Ramsey, 1995, 2001; Reimer et al., 2004) taking into account a global reservoir age of $400 \mathrm{yr}$ and a regional correction $\Delta \mathrm{r}=163 \pm 74 \mathrm{yr}$ (Southon et al., 2002).The resulting age-depth profile (Figure 3, right) shows that sedimentation rates vary from a minimum $\sim 28 \mathrm{~cm} / \mathrm{ka}$ between 10000 and $6500 \mathrm{cal}$ yr BP to a maximum of $\sim 85 \mathrm{~cm} / \mathrm{ka}$ between 10000 and $11000 \mathrm{cal} \mathrm{yr} \mathrm{BP.}$

\subsection{Pollen analyses}

Ninety-fivesampleswere taken through the $9.5 \mathrm{~m}$ core for pollen,fresh water algae and charcoal analyses at interval varying from 6 to $25 \mathrm{~cm}$, with a special focus on the last deglaciation. Samples were processed according to standard procedures (chemical treatment with HCL and HF, sieving at $5 \mu \mathrm{m}$ ) (Faegri and Iversen, 1975). Pollen and spores counts ranged from44 to 380.Percentages were calculated on the total of grains counted, undeterminable ones excluded. Identification of 77 pollen and spore taxa (Table 2) was possible using the extensive reference material of the African Pollen Database (APD) and regional pollen atlases (El-Ghazali, 1991; Bonnefille and Riollet, 1980; Bonnefille, 1971). Nomenclature followed Vincens et al. (2007). Terrestrial Non Pollen Palynomorphs (freshwater algae, fungi and charcoal) were identified and counted from the same samples and their percentages were calculated separately.

Addition of a known concentration of an exotic pollen taxon (Alnus rubra) prior to processing made possible to estimatefluxes of all these terrestrial elements.Data are presented in the form of a percentage diagram (Figure 4) using TILIA 2.0 andCONISS (Grimm et al., 1993) 


\section{Results}

Three herbaceous taxa: Amaranthaceae/Chenopodiaceae, Poaceae and Cyperaceae dominate the pollen sequence with maximum values of 57, 51 and $43 \%$ respectively. They display opposite trends, with Amaranthaceae/Chenopodiaceae progressively decreasing from the base to the top of the sequence and Poaceae and Cyperaceae progressively increasing. Four main zonescan be distinguished:

Zone 1 (19.2-13.5ka):Thiszone exhibits the predominance of steppic pollen types mainly Amaranthaceae/Chenopodiaceae, Asteraceae, Acacia, Ephedra and Artemisia. Low values of freshwater algae and ferns suggest reduced river transport to the core site. Pollen grains from Afromontane regions (Podocarpus and Juniperus) testify to the long distance wind transport. Two sub-zones can be distinguished on both sides of the 15.7 ka level with sub-zone $1 \mathrm{~b}$ characterized by higherpercentages of charcoal fragments and lower pollen diversity(Figure 4) and influxes(Figure 5) compared to sub-zone 1a.

Zone 2 (13.5-10 ka): In this transition interval, the progressive decline of dry indicators (particularly Asteraceae) is counterbalanced by the increase in pollen diversity from the nearby semi-arid grasslands and deciduous woodland (e.g., Combretaceae, Capparis, Dipterygium...), the littoral mangroves (Avicennia and Rhizophora) and the tropical highlands (Olea and Hagenia). As a result, this zone records the increaseof influxes of all terrestrial elements including charcoal particles, which display high amplitude fluctuations (Figure 4).

Zone 3 (10-6.4 ka):10ka marks an abrupt shiftfroma predominantly dry period to a more humid one: Amaranthaceae/Chenopodiaceae percentages dramatically fall from a maximum of $59 \%$ in the preceding zone to a minimum of $18.5 \%$ whereas Combretaceae, associated with taxa from tropical humid environments increase in conjunction with an increase in mangrove 
taxa (e.g., Sapotaceae, Rhizophora), Cyperaceae, fern spores, freshwater algae and fungi, reflecting continental humidity and river inputs (Figure 4). Influxes strongly decrease from the base of this zone, then remain relatively stable (pollen, charcoal) or slightly decrease (fungi) up to the top of the sequence (Figure 5).

Zone 4 (6.4-0.4 ka): In this zone the decrease and disappearance of Rhizophora and the increase of steppic taxa (e.g., Amaranthaceae/Chenopodiaceae, Asteraceae, Artemisia and Tribulus) reflect the decline of humidity (Figure 4). Two sub-zones are distinguished:in subzone $4 \mathrm{a}(6.4$ to $4 \mathrm{ka})$, high percentages of Cyperaceae suggest the persistence of relative humid conditions in the surroundings. In sub-zone $4 \mathrm{~b}(4 \mathrm{ka}-0)$, the decline of this taxon together with the reappearance of dry elements Artemisia and Tribulus indicate the setting of the modern arid to semi-arid environmental conditions. The presence of Pinus moreover suggests the increased importance of pollen transport from the Mediterranean areas. Influxes of freshwater algaeincrease in zone 4 showing the permanence of local river transport to the Gulf of Aden in spite of regional dryness.

\section{Discussion}

\subsection{Regional environment}

Pollen data from Arabia and the Horn of Africa are very rarefor periods before the Holocene. Lake Tana (Lamb et al., 2007) provides evidence that semi-desert herbaceous vegetation developed in the highlands of Northern Ethiopia $\left(12^{\circ} \mathrm{N}\right)$ between 16.4 and 15.2 ka testifying to the arid climate conditions. Similar xerophytic environments were present farther South at e.g. Garba Guracha (652N - Umer et al., 2007) or Mount Badda (752 N - Hamilton, 1982) in the Ethiopian Highlands before their replacement by well-developed montane forests after13.4ka. In the Rift valley, the landscape was highly heterogeneous: montane forest 
developed near lake Abiyata since $12.2 \mathrm{ka}\left(7^{\circ} 37 \mathrm{~N}\right.$ - Lézine and Bonnefille, 1982) whereas savanna dominated to the South at Tilo $\left(7^{\circ} 03 \mathrm{~N}\right.$ - Lamb et al. (2001) throughout the Holocene. No such a vegetation evolution - i.e. post-glacial development of montane forests is recorded in core MD92-1002, which points to the continuous presence of semi-desert vegetation of Somalia-Masai type from $20 \mathrm{ka}$ to the present day. This pattern likely corresponds to what is observed in the Southern Arabian lowlands during the Holocene as reported by the al-Hawa pollen sequence $\left(15^{\circ} 52 \mathrm{~N}\right.$ - Lézine et al., 2010). However, owing to the fact that the Somalia-Masai vegetation zone encompasses today the Gulf of Aden (Figure 2), it is difficult to discriminate the northern or the southern origin of the pollen grains transported to the core site and to definitively exclude any contribution of the Horn of Africa. Indeed, pollen taxa from Afromontane forests: Podocarpus, Juniperus, Olea and Hagenia have been found in many samples of core MD92-1002. Nevertheless, except for Hagenia, which is absent in Arabia, all the other pollen types may originate from either the Ethiopian or Arabian highlands (Gazanfar and Fisher, 1998; Hepper and Wood, 1979). Their very low contributions make it difficult to define their precise origin. In contrast, the importance of Asteraceae and the occurrence of Artemisiaand Ephedrafrom 19.2 to 10ka then from $6.4 \mathrm{ka}$ to the present (zones 1,2 and 4) point to the contribution of northern steppic ecosystems of Saharo-Sindian affinity since these pollen taxa characterize modern pollen samples from sectors of the Arabian peninsula to the North and North-East, out of direct influence of tropical climate (El Moslimany, 1983; Bonnefille and Riollet, 1988; Lézine et al. 1998, 2002, 2010).Among these two arid periods, the time interval from 20 to 13.5 kawasindisputably the driest, characterized by the dominance of plants tolerant to dry climate conditions and/or saline environments (e.g., Amaranthaceae/Chenopodiaceae) and by a poorly diverse regional flora with Acacia and diverse Capparidaceae among the rare trees and shrubs. Continuous presence of Artemisia, Ephedra, together with Asteraceae indicates that long-distance 
transport from northern origin was dominant and maximum influx of pollen grains and charcoal fragmentssuggests strong wind activity. Nevertheless, ferns spores and freshwater algae present at the base of thisperiodsuggest that local humidity persisted in spite of regional dryness. The second period of marked aridity, between 6.4 to 0ka,differs from the previous one by a more diverse flora, typically of Somalia-Masai origin and by significant values of all humid indicators (Cyperaceae, ferns, fresh water algae, fungi). These, together with the high values of Poaceae show that this time interval was less dry compared to the 20-13.5 ka interval, with a more continuous herbaceous cover on the nearby continentscompared to the last glacial period. However, the presence of Artemisia among the herbaceous plant types point to strong winds from northern origin. This pattern is accentuated from $4 \mathrm{ka}$ onward as evidenced by the appearance of Pinus from Mediterranean origin and the dramatic decrease of Cyperaceae percentages.

These resultsare congruent with earlier observations by Sirocko et al. (1993) on core KL74 from the Arabian Sea in which the dolomite fraction is interpreted as reflecting the efficiency of wind transport from the Arabian peninsula and the Persian Gulf. In this core, dolomite contribution is higher during two periods: the last glacial up to $15.3 \mathrm{ka}$ and the mid- to late Holocene, after 7.3ka (Figure 6A).The KL74 dolomite record is particularly asymmetrical on both sides of the Holocene humid Period. Maxima of \%dolomite reached during the last glacial are at least 3 timeshigher (or more) than those of the late Holocene. Even though the last glacial maxima of KL74 dolomite may have been amplified by terrestrial inputs from large dessicated areas such as the Persian Gulf (Sirocko et al., 1993; Lézine et al., 2014), pollen record from core MD92-1002 suggests that wind activity and correlative dryness werehigher during the last glacial than during the Holocene humid period. This pattern is also evidenced by the $\delta \mathrm{D}$ wax record from nearby core P178-15P,which never falls down to glacial values during the late Holocene (Tierney and deMenocal, 2013; Figure 6E).Such a 
temporalevolution, characterized by dryer conditions during the last glacial compared to the late Holocene, contrasts with what has been reconstructedat the northern edge of the Atlantic monsoon system on western Africa (Lézine et al., 2014 and references therein). At Site ODP 658, located off Cap Blanc (Mauritania) below the summer African dust plume, sedimentation of windborne material transported from the sub-Saharan and Sahel regions was as importantduring the last $5.5 \mathrm{ka}$ than during the last glacial period (deMenocal et al., 2000)

\subsection{Local hydrology and relations with the surrounding land masses}

In order to discuss the timing of humidity increase at the onset of "Holocene Humid Period"in the Gulf of Aden and its surroundings, we have built a"Humidity Pollen Index" (HPI)by calculating the ratio between two major pollen taxa occurring regionallyand illustrating two opposite environmental conditions: the most humid, Cyperaceae and the most arid, Amaranthaceae/Chenopodiaceae. In addition, we have considered mangrove taxa and especially Rhizophora as reflecting local humidity, i.e., the influence of summer monsoon rainfall at the core site. Non-significant variations of these two humid indicators were smeared out by performing a 5-point window moving average (Figure6B).PHI shows that humidity increased since 14.9 kain agreement with earlier paleohydrological and paleoclimatic studies based on East African lakes(e.g. Foerster et al., 2012; Tierney and deMenocal, 2013; Figure 6E) and speleothems from Socotra (Shakun et al., 2007; Van Rampelbergh et al., 2013) which date the onset of the post glacial humidity increase from 14.68-14.5 ka (Figure 6D). Such an early increase in humidity is also evidenced in the development of lakes and wetlands over the Horn of Africa (Lézine et al., 2010, 2014; Figure $6 \mathrm{~F})$, although the signal remains weak. The trend of humidityin the pollen record from core MD92-1002 was punctuated by two phases of return to dryer conditions: at $12.7 \mathrm{ka}$, then at $10.4 \mathrm{ka}$, in phase with periods of enhanced wind activity of N-S direction responsible for dust 
transport from the Arabian peninsula to the ocean as recorded by the KL74 dolomite record (Figures 6A and 6B). Mangrove expansion at $13.5 \mathrm{ka}$ started in a regional context of aridity as shown by the only occurrence of Avicennia, which is particularly adapted to arid and hyper saline conditions. Humidity increased sufficiently to allow Rhizophora to expand one millennium after, at $12.6 \mathrm{ka}$. Rhizophora mucronata is a tropical species, which requires fresh water from both rivers and summer rainfall and stable environmental conditions. In palaeoenvironmental studies it is usually used as a marker of both sea level variations (Lézine, 1996) and monsoon rainfall (Overpeck et al., 1996). The development of mangrove in the Gulf of Aden occurred during a phase of relative sea level stability just after Meltwater Pulse 1a ( 14 ka; e.g., Bard et al., 1996; Stanford et al., 2006). Then Rhizophora reached its maximum between 9 and $7.5 \mathrm{ka}$ in response to increased influence of summer monsoon rains in the Gulf of Aden. The timing of this "climate optimum" in the Gulf of Aden closely matches paleohydrological data showing the expansion of open water bodies in southern Arabia (Lézine et al., 2010; 2014; Figure 6C) and the optimum humidity interval evidenced by low $\delta^{18} \mathrm{O}$ values from the Qunf-5 isotope record from southern Oman (Fleitmann et al., 2003; Figure 6D).

The termination of the African Humid Period in the Gulf of Aden took place in three main steps: Rhizophora started to decline as soon as $7.5 \mathrm{ka}$ (Figure 6B), synchronously with the progressive increase of $\delta^{18} \mathrm{O}$ (decreased humidity) recorded in the nearby, southern Oman Qunf speleothem record (figure 6D)and definitively collapsed at 5.5 ka (Figure 6B). This timing is in accordance with the drying out of the lakes and wetlands in the Arabian lowlands (Lézine et al., 2014; Figure 6C). Finally, HPI drops at 4 ka recording the end of the regionalhumidity. This humidity decrease at 4 ka suggests links with the East African hydrology, wherea pronounced environmental shift was recorded at about 4,000 years BP by multiple lines of evidence (Marchant and Hooghiemstra, 2004). However, the short phase of 
positive hydrological balance around 2.5ka recorded in northern Ethiopia and the Horn of Africa (Gasse and Van Campo, 1994) (Figure 6) is not visible in our record.

\subsection{Humidity evolution and ITCZ dynamics over the Horn of Africa and Arabia}

There are still ongoing discussions about the timing and abruptness of the HHP onset (e.g. deMenocal et al., 2000; Kröpelin et al., 2008; Foerster et al, 2012; Thierney and deMenocal, 2013). As seen above, the HHP onset appears as a rather abrupt and large amplitude swing inthe Socotra speleothem isotope record (Shakun et al., 2007; Van Rampelbergh et al., 2013; Figure 6D) and the dolomite content of marine core 74KL (Sirockoet al., 1993; Figure 6A). This is in contrast with the reconstruction of lake and wetland expansion over the Horn of Africa and over Arabia, which suggests a rather subtle and gradual increase of humidity (Figures 6C and 6F) - such a progressive evolution being more in line with the gradual change in pollen humidity index from core MD92-1002. Part of the discrepancy in shape and amplitude between humidity records in Figure 6 likely reflectsthe factthat changes inmonsoonal precipitationscan beassociated with spatial shift of the ITCZ summer position at orbital or sub-orbital timescales (e.g. Peterson et al., 2000; Haug et al., 2001). Regional synthesis of humidity records (i.e. Lézine et al., 2011, 2014) or proxies reflecting regional humidity changes, willtendto provide a smoothed and more gradual signal than records of local humidity, wheneverITCZ meandering chiefly controls the spatial distribution and time evolution of precipitation changes.

When focusing onthe records that reflect local humidity changes, it may be possible to reconstruct those spatio-temporal shifts of ITCZ position. For this goal, we focused on (i) the three speleothem isotopic records (Socotra, Qunf, Hoti; Neff et al., 2001; Fleitmann et al., 2007; Shakun et al., 2007; Van Rampelbergh et al., 2013), which provide direct indication of precipitation history over the cave locations, and (ii) the Rhizophora\% record from core 
MD92-1002. These records are displayed versus age in Figure 7together with HPI, which provides a more regional humidity signal over Arabia. These records are distributed vertically with respect to their respective latitudinal position. As can be seen from Figure 7, the change in humidity at the HHP onset and across the deglaciation shows a clear spatio-temporal structure. Speleothem records from Socotra and Oman strongly support evidence of a latitudinal, time-transgressive pattern of rainfall increase from $14.51 \mathrm{ka}\left(\right.$ Socotra $\left.-12^{\circ} 30 \mathrm{~N}\right)$, $11.4 \mathrm{ka}\left(\mathrm{Qunf}-17^{\circ} 35 \mathrm{~N}\right)$ and $10 \mathrm{ka}\left(\right.$ Hoti $\left.-23^{\circ} \mathrm{N}\right)$. Together with sedimentological data from Chew Bahir basin, which suggest a rise in humidity as early as 19 ka over Southern Ethiopia (Foerster et al., 2012), these data clearly depict a northward motion of humidity maximum which likely reflects the latitudinal meandering of the ITCZ In addition, combining the speleothem records with our pollen series from core MD92-1002 makes it also possible to reveal a westward motion ofITCZ through time. The first abrupt increase in humidity recorded at $\sim 14.5 \mathrm{ka} \mathrm{BP}$ in the Socotra speleothem, corresponds to a humidity increase also recorded in the HPIrecord from MD92-1002 at about the same latitude. But after amaximum of humidity at about 14-13.5 ka BP, the two records show an opposite evolution:the Socotra isotopic record shows a progressive decline in humidity at $12^{\circ} 30 \mathrm{~N}$, whilecore MD92-1002 HPI indicates increasinghumidity northward, over Arabia. The mangrove started its expansion in the vicinity of core MD92-1002 as about $~ 12.5 \mathrm{ka} \mathrm{BP}$, as is attested by the first occurrenceand later increase of Rhizopora pollen. Taken at face value, decline of humidity over Socotra while it increased in the vicinity of MD92-1002 suggests a westward displacement of the ITCZ, which moved landward as summer insolation increased. Rhizophora \% shows a marked increase at $\sim 11.5 \mathrm{ka} \mathrm{BP,} \mathrm{coeval} \mathrm{with} \mathrm{a} \mathrm{final} \mathrm{burst} \mathrm{of} \mathrm{humidity}$ over Socotra, which corresponds to the "swan song" of the speleothem, after which it stopped to develop. The subsequent Qunf speleothem development and the gradual increase of Rhizophora abundance and HPI through the rest of the deglaciation in core MD92-1002, 
clearly indicate that summer ITCZ position had been permanently shifted towards west and north of Socotra after $\sim 11 \mathrm{ka} \mathrm{BP}$.

\section{Conclusions}

Pollen analyses fromsediment coreMD92-1002 (Gulf of Aden) make it possible to derive a high-resolution record of hydro-climate evolution at the junction between the Horn of Africa and the Arabian Peninsula since the LGM. These palynological data reveal relatively gradual changes in humidity at the onset and decline of the Holocene Humid Period. Humidity increased since about $14.9 \mathrm{ka} \mathrm{BP}$ and reached a maximum between 9-7.5 ka BP, in agreement with paleohydrological data from southern Arabia (Lézine et al., 2014).Changes in humidity at the onset of HHP reflect variations in monsoonal precipitation associated to the progressive migration of the ITCZ. This is readily seen from the northward and westward spatio-temporal pattern of humidity changes, which emerges from the comparison of a local humidity indicator in Core MD92-1002 (Rhizophora\%, associated to mangrove development)with speleothem isotopic records from Socotra and the Arabian Peninsula (Neff et al., 2001; Fleitmann et al., 2007; Shakun et al., 2007; Van Rampelbergh et al., 2013). The HHP ended up gradually, starting to decline as soon as $7.5 \mathrm{ka}$ and collapsing definitively at $5.5 \mathrm{ka}$. This decline is characterized by the appearance of Mediterranean taxa and the return of arid conditions, comparable to that of today.

\section{Acknowledgements}

We thank Kevin Lemonnier (LOCEAN) for his helpful support for laboratory assistance, pollen analysis and identification, Fatima Manssouri (LSCE) for isotopic analyses and Fabien Dewilde (LSCE) for isotopic analyses and quality control.AMS dating was provided by UMS-ARTEMIS (LMC14, Saclay, France) AMS Facilities. This study has been supported by 
two French projects: ANR-MONOPOL (Blanc SIMI 5-6) and ANR EL PASO (ANR-10-

BLAN-0608). WF and F. B are supported by CEA (France) and AML by CNRS (France).

This is LSCE contribution number XXXX.

\section{References}

Bard, E., Hamelin, B., Arnold, M., Montaggioni, L., Cabioch, G., Faure, G., Rougerie, F., 1996.Deglacial sea-level record from Tahiti corals and the timing of global meltwaterdischarge.Nature 382, 241-244.

Barker, P.A., Talbot, M.R., Street-Perrott, F.A., Marret, F., Scourse, J., Odada, E.O., 2004.Late Quaternary climatic variability in Intertropical Africa. In: Battarbee, R., Gasse, F., Stickley, F. (Eds.), Past Climate Variability Through Europe and Africa. Springer, Dordrecht, pp. 117-138.

Bassinot, F.C., Marzin, C., Braconnot, P., Marti, O., Mathien-Blard, E., Lombard, F., Bopp, L., 2011.Holocene evolution of summer winds and marine productivity in the tropical Indian ocean in response to insolation forcing: data-model comparison. Climate of the Past 7, 815-829.

Bonnefille, R., 1971.Atlas des pollens d'Ethiopie.Pollens actuels de la basse vallée de l'Omo. Récoltes botaniques 1968. Adansonia 11, 463-518.

Bonnefille, R., Riollet, G., 1980. Pollens des savanes d'Afrique orientale. CNRS Editions, Paris.

Bonnefille, R., Riollet, G., 1988. The Kashiru Pollen Sequence (Burundi) Palaeoclimatic Implications for the Last 40,000 yr B.P. in Tropical Africa.Quaternary research 30, 1935.

Bouilloux, A., Valet, J.-P., Bassinot, F., Joron, J.L., Dewilde, F., Blanc-Valleron, M.-M., Moreno, E., 2013a. Influence of seawater exchanges across the Bab-el-Mandeb Strait on 
sedimentation in the Southern Red Sea during the last 60 ka. Paleoceanography 28, $675-687$.

Bouilloux, A., Valet, J.P., Bassinot, F., Joron, J.L., Blanc-Valleron, M.M., Moreno, E., Dewilde, F., Kars, M., Lagroix, F., 2013b. Diagenetic modulation of the magnetic properties in sediments from the Northern Indian Ocean. Geochemistry Geophysics Geosystems 14, 3779- 3800 .

Bronk Ramsey, C., 1995.Radiocarbon calibration and the analysis of stratigraphy. Radiocarbon 37, 425-30.

Bronk Ramsey, C., van der Plicht, J., Weninger, B., 2001. 'Wiggle matching' radiocarbon dates. Radiocarbon 43, 381-9.

Castañeda, I., Mulitza, S., Schefuß, E., Lopes dos Santos, R.A., SinningheDamsté, J.S., Schouten, S., 2009. Wet phases in the Sahara/Sahel region and human migration patterns in North Africa. Proceedings of National Academy of Sciences of the United States of America 106, 20159-20163.

Clemens, S.C., Prell, W.L., 1990. Late Pleistocene variability of Arabian Sea summer monsoon winds and continental aridity: eolian record from the lithogenic components of deep sea sediments. Paleoceanography 5, 109-145.

COHMAP Members, 1988. Climatic changes of the last 18,000 years: observations and model simulations. Science 241, 1043-1052.

deMenocal, P., Ortiz, J., Guilderson, T., Adkins, J., Sarnthein, M., Baker, L ., Yarusinsky, M., 2000. Abrupt onset and termination of the African Humid Period: rapid climate responses to gradual insolation forcing. Quaternary Science Reviews 19, 347-361.

El-Ghazali, G.A., 1991.Pollen Flora of Qatar.University of Qatar, Scientific and Applied Research Centre, Doha. 
El-Moslimany, A.P., 1983.History of climate and vegetation in the Eastern Mediterranean and the Middle East from the Pleniglacial to the Mid-Holocene, $\mathrm{PhD}$ thesis, University of Washington.

Faegri, K., Iversen, J., 1975. Textbook of Pollen Analysis. Blackwell, Oxford.

Fleitmann, D., Burns, S.J., Mangini, A., Mudelsee, M., Kramers, J., Villa, I., Neff, U., AlSubbary, A.A., Buettner, A., Hippler, D., Matter, A., 2007. Holocene ITCZ and Indian monsoon dynamics recorded in stalagmites from Oman and Yemen (Socotra). Quaternary Science Reviews 26, 170-188.

Foerster, V., Junginger, A., Langkamp, O., Gebru, T., Asrat, A., Umer, M., Lamb, H.F., Wennrich, V., Rethemeyer, J., Nowaczyk, N., Trauth, M.H., Schaebitz, F., 2012. Climatic change recorded in the sediments of the Chew Bahir basin, southern Ethiopia, during the last 45, 000 years. Quaternary International 274, 25-37.

Gasse, F., 1977.Evolution of Lake Abhé (Ethiopia and T.F.A.I.) from 70000 B.P. Nature 2, $42-45$.

Gasse, F., Fontes, J.-C.,1989. Paleoenvironments and paleohydrology of a tropical closed lake (Lake Asal, Djibouti) since 10,000 yr B.P.

Palaeogeography,Palaeoclimatology,Palaeoecology 69, 67-102.

Gasse, F., Van Campo, E., 1994.Abrupt post-glacial climate events in West Asia and North Africa monsoon domains.Earth and Planetary Science Letters 126, 435-456.

Gasse, F., Chalié, F., Vincens, A., Williams, M.A.J., Williamson, D., 2008. Climatic patterns in equatorial and southern Africa from 30000 to 10000 years ago reconstructed from terrestrial and near-shore proxy data. Quaternary Science Reviews 27, 2316-2340.

Ghazanfar, S.A., Fisher, M.,1998.Vegetation of the Arabian Peninsula Geobotany 25, 1 362. 
Grimm, E.C., 1993. TILIA: A pollen program for analysis and display. Illinois State Museum, Springfield.

Hamilton, A.C., 1982. Environmental History of East Africa: a Study of the Quaternary. Academic Press, London.

Haug, G.H., Hughen, K.A, Sigman, D.M., Peterson, L.C., 2001. Southward migration of the intertropical convergence zone through the Holocene, Science 293, 1304-1308.

Hepper, F.N., Wood, J.R.J., 1979. Where there forests in the Yemen? Proceedings Seminar of Arabian Studies 9, 65-71.

Kröpelin, S., Verschuren, D., Lézine A.-M., Eggermont, H., Cocquyt C., Francus, P., Cazet, J.-P., Fagot, M., Rumes, B., Russell, J.M., Darius, F., Conley, D.J., Schuster, M., Von suchodoletz, H., Engstrom, D.R., 2008. Climate-driven ecosystem succession in the Sahara: the past 6000 years. Science 320, 765-768.

Kutzbach, J.E., Street-Perrot, F.A., 1985. Milankovitch forcing of fluctuations in the level of tropical lakes from 18 to 0 kyr BP. Nature $317,130-134$.

Lamb, H.F., 2001. Holocene climatic change and vegetation response inferred from the sediments of Ethiopian crater lakes. Proceedings of the Royal Irish Academy 101B, 35 46.

Lamb, H.F., Bates, C.R., Coombes, P.V., Marshall, M.H., Umer, M., Davies, S.J., Eshete, D., 2007.Late Pleistocene desiccation of Lake Tana, source of the Blue Nile.Quaternary Science Reviews 26, 287-299.

Léonard, J., 1989. Considérations phytogéographiques sur les phytochories IranoTouranienne, Saharo-Sindienne et la Somalie- Pays Masai.In:Léonard, J., Considérations à l'étude de la flore et de la végétation des déserts d'Iran. Jardin botanique national de Belgique, pp 123. 
Leuschner, D. C., Sirocko, F.,2000. The low-latitude monsoon climate Dansgaard-Oeschger cycles and Heinrich Events.Quaternary Science Reviews 19, 243-254.

Lézine, A.-M., Bonnefille, R., 1982. Diagramme pollinique Holocène d'un sondage du lac Abiyata(Ethiopie, 7 degrés 42' nord).Pollen et Spores 24, 463-480.

Lézine, A.-M., 1996. La mangrove ouest africaine, signal des variations du niveau marin et des conditions régionales du climat au cours de la dernière déglaciation.Bulletin de la Société Géologique de France 167, 743-752.

Lézine, A.-M., Saliège, J.-F., Robert, C., Wertz, F., Inizian, M.L., 1998. Holocene lakes from Ramlat As-Sab'atayn (Yemen) illustrate the impact of monsoon activity in southern Arabia. Quaternary Research 50, 290-299.

Lézine, A.-M., Saliège, J.-F., Mathieu, R., Tagliatela, T.L., Mery,S., Charpentier, V., Cleuziou,S., 2002. Mangroves of Oman during the Late Holocene: climatic implications and impact on human settlements. Vegetation History Archaeobotany 11. 221-232.

Lézine, A.-M., Robert,C., Cleuzious, S., Inizan, M.-L., Braemer, F., Saliege, J.-F., Sylvestre, F., Tiercelin, J.-J., Crassaard, R., Méry, S., Charpentier, V., Steimer-Herbet, T., 2010. Climate evolution and human occupation in the southern Arabian lowlands during the last deglaciation and the Holocene. Global and Planetary Change 72, 412-428.

Lézine, A.-M., Hély, C., Grenier, C., Braconnot, P., Krinner, G., 2011. Sahara and Sahel vulnerability to climate changes.Lessons from paleohydrologicaldata.Quaternary Sciences Reviews 30, 3001-3012.

Lézine, A.-M., Bassinot, F., Peterschmitt, J.-Y., 2014. Orbitally-induced changes of the Atlantic and Indian monsoons over the past 20,000 years: New insights based on the comparison of continental and marine records. Bulletin de la Société Géologique de France 185, 3-12. 
Liu, Z., Brady, E., Lynch-Steiglitz, J., 2003. Global ocean response to orbital forcing in the Holocene.Paleoceanography 18, 1029-1041.

Marchant, R.A., Hooghiemstra, H., 2004. Rapid environmental change in African and South American tropics around 4000 years before present: a review. Earth Science Reviews $66,217-260$.

Marzin, C., Braconnot, P., 2009. Variations of Indian and African monsoons induced by insolation changes at 6 and 9.5 kyr BP. Climate Dynamics 33, 215-231.

Mathien-Blard, E., 2008. Révision du paléothermomètre $\mathrm{Mg} / \mathrm{Ca}$ et son application sur l'hydrologie de surface de l'Océan Indien Tropical au cours de l'Holocène. PhD thesis, University Paris XI.

Neff, U., Burns, S.J., Mangini, A., Mudelsee, M., Fleitmann, D., Matter, A., 2001. Strong coherence between solar variability and the monsoon in Oman between 9 and 6 kaago.Nature 411, 290-293.

Ouahdi, R., 1997. Paléocéanographie et paléoproductivité liées à la mousson indienne dans le bassin de Somalie, le Golfe d'Aden et la mer Rouge durant les derniers 460000 ans. PhD thesis, MNHN Paris.

Overpeck, J., Anderson, D., Trumbore, S., Prell, W., 1996.The southwest Indian Monsoon over the last 18000 years.Climate Dynamics 12, 213-225.

PERSGA, 2004. The Regional Organization for the Conservation of the Environment ofthe Red Sea and Gulf of Aden: Status of Mangroves in the Red Sea and Gulf of Aden (09/05/2004).

Peterson, L.C., Haug, G.H., Hughen, K.A., Röhl, R., 2000. Rapid changes in the hydrologic cycle of the Tropical Atlantic during the Last Glacial.Science 290, 1947-1951.

Prell, W. L., Kutzbach, J. E., 1987.Monsoon variability over the past 150,000 years.Geophysical Research 92, 8411-8425. 
Reimer, P.J., Brown, T.A., Reimer, R.W., 2004. Discussion: reporting and calibration of postbomb 14C data. Radiocarbon 46, 1299-304.

Renssen, H., Brovkin, V., Fichefet, T., Goosse, H., 2006. Simulation of the Holocene climate evolution in northern Africa: the termination of the African humid period. Quaternary International 150, 95-102.

Shakun, J.D., Stephen J. Burns, S.J., Fleitmann, D., Kramers, J., Matter, A., Al-Subary, A., 2007. A high-resolution, absolute-dated deglacialspeleothem record of Indian Ocean climate from Socotra Island, Yemen. Earth and Planetary Science Letters 259, 442456.

Sheppard, C. R. C., 2000.The Red Sea at the millennium, an environmental evaluation. In:

Sheppard, C. R. C. (Ed), Elsevier Science, 35-45.

Sirocko, F., Sarnthein, M., Erlenkeuser, H., Lange, H., Arnold, M., Duplessy, J.-C., 1993.Century-scale events in monsoonal climate over the past 24,000 years. Nature 364 , $322-324$.

Sirocko, F., Garbe-Schönberg, D., Devey, C., 2000.Processes controlling trace element geochemistry of Arabian Sea sediments during the last 25,000 years. Global and Planetary Change 26, 217-303.

Southon, J., Kashgarian, M., Fontugne, M., Metivier, B., Yim, W.W.S., 2002.Marine reservoir corrections for the Indian Ocean and Southeast Asia. Radiocarbon 44, $167-$ 180.

Spalding, M., Kainuma, M., Collins, L., 2010.World atlas of mangroves. Washington, DC: Earthscan.

Stanford, J.D., Rohling, E.J., Hunter, S.E., Roberts, A.P., Rasmussen, S.O., Bard, E., McManus, J., Fairbanks, R.G., 2006. Timing of melt water pulse 1a and climate responses to melt water injections. Paleoceanography 21, 1-9. 
Stein, M., Almogi-Labin, A., Goldstein, S. L., Hemleben,C., Starinsky, A., 2007. Late

Quaternary changes in desert dust inputs to the Red Sea and Gulf of Aden from ${ }^{87} \mathrm{Sr} /{ }^{86} \mathrm{Sr}$ ratios in deep-sea cores. Earth Planetary and Science Letter 261, 104-119.

Tierney, J.E., deMenocal, P.B., 2013. Abrupt Shifts in Horn of Africa Hydroclimatesince the Last Glacial Maximum.Science 1126, 1- 10.

Umer, M., Lamb, H.F., Bonnefille, R., Lézine, A.-M., Tiercelin, J.J., Gibert, E., Cazet, J.-P., Watrin, J., 2007.Late Pleistocene and Holocene vegetation history of the Bale Mountains, Ethiopia. Quaternary Science Reviews 26, 2229-2246.

Van Rampelbergh, M., Fleitmann, D., Verheyden, S., Cheng, H., Edwards, L., De Geest, P., De Veleechouwer, D., Burns,S.J., Matter, A., Claeys, P., Keppens, E., 2013. Mid- to late Holocene Indian ocean monsoon variability recorded in four speleothems from Socotra Island, Yemen. Quaternary Science Reviews 65, 129-142.

Van Weering, T.C.E., Helder, W., Schalk, P., 1997. The Netherlands Indian Ocean Expedition 1992-1993, first results and an introduction. Deep Sea Research II, 44, 1177-1193.

Vincens, A., Lézine, A.-M., Buchet, G., Lewden, D., Le Thomas, A. and contributors., 2007b. African pollen database inventory of tree and shrub pollen types.Review of Palaeobotany and Palynology 145, 135-141.

White,F., 1983. The vegetation of Africa: a descriptive memoir to accompany the UNESCO, AETFAT, UNESCO vegetation map of Africa. Paris.

White, F., Leonard, J., 1991.Phytogeographical links between Africa and southwest Asia. Flora and Vegetation Mundi 9, 229-246.

Wood, J. R. I., 1997. A Handbook of Yemen Flora.Royal Botanic Gardens, Kew. Zohary, M., 1973.Geobotanical foundations of the Middle East.Gustav Fischer Verlag.Stuttgart 2, 729-739. 


\section{Figure Captions}

Fig 1. Surface wind trajectories (1000 hP) during the summer (JJA) and winter (DJF; (ECMWF analyses 1990-1997). Location of core MD92-1002.

Fig 2. Topographical/bathymetrical map of the Gulf of Aden and the surrounding continental areas showing the location of core MD92-1002 and the other sites cited in the text. Phytogeographical zones are fromWhite (1983), Leonard (1989), White and Leonard (1991). SM: Somalia-Masai;A: Afromontane; Sa: Sahel; SS: Saharo-Sindian(SS1: Saharan, SS2: Arabian andSS3; Nubo-Sindian);Sd: Sudanian;Gc: Guineo-Congolian/Sudanian.

(1) Socotra stalagmite (Shakun et al., 2007); (2) Core MD92-1002 (this study); (3) Qunf stalagmite (Fleitmann et al., 2003); (4) Hoti stalagmite (Neff et al., 2001); (5) al Hawapaleolake records (Lézine et al., 2010); (6) Core KL74 (Sirocko et al., 1993); (7) Core P178-15P (Tierney and deMenocal, 2013); (8) Lake Tana (Lamb et al., 2007); (9) Lake Abiyata (Lézine and Bonnefille, 1982); (10) Lake Tilo (Lamb et al., 2001); (11) Garba Gurcha (Umer et al., 2007); (12) Mount Badda (Hamilton ,1982); (13) Chew Bahir basin ( Foerster et al., 2012).

Fig 3.Isotopic stratigraphy of core MD92-1002 (left) and depth-age profile based on ${ }^{14} \mathrm{C}$ dating (right). Age model development and uncertainty propagation were obtained by using the Oxcal software (Bronk Ramsey, 1995, 2001; Reimer et al., 2004).

Fig 4. Synthetic pollen diagram showing, versus calendar chronology,(i/Left) main pollen and spore taxa according to their origin: montane forests, lowland steppes and deserts and 
mangroves (percentages calculated against the sum of pollen and spores), and (ii/Right) terrestrial non-pollen palynomorphs (NPP) (percentages calculated to the sum of all terrestrial elements (pollen, spores and NPP).

Fig 5. Synthetic diagram showing the influx (number of grains per $\mathrm{cm}^{2}$ per year) of all the terrestrial elements of core MD92-1002 versus calendar chronology.

Fig 6.Paleoenvironments of the Gulf of Aden from 20 ka to the present.A: Dolomite record from core KL74 (inverted scale) from the Arabian Sea (Sirocko et al.,1993) illustrating fluctuations of aridity and wind strength of $\mathrm{N}-\mathrm{S}$ direction (with peaks during humid periods);

B: Humidity Pollen Index and Rhizophora curve (5-sample running average) from core MD92-1002 (this study); C: Dated records of lakes and wetlands in Arabia (Lézine et al., 2014); D: Oxygen isotope records from three speleothem records in Oman and Yémen: from North to South (Hoti $\left(23^{\circ} 05^{\prime} \mathrm{N}\right.$, Neff et al., 2001), Qunf (17010'N , Fleitmann et al., 2003) Socotra ((12³0'N, Shakun et al.,2007); E. $\delta D_{\text {wax }}$ from core P178-15P (Tierney and deMenocal, 2013); F. Dated records of lakes and wetlands in the Horn of Africa (Lézine et al., 2014).

Fig 7. Focus on local humidity changes during the last deglaciation. Location of all records is shown in map as well as the summer position of ITCZ (dotted line). (1) : Oxygen isotope data from Socotra speleothem (Yemen) (Shakun et al., 2007); (2) hydrological proxies from core MD92-1002 (this study) ; (3) stalagmite oxygen isotope record from South Oman (Fleitmann et al., 2003); (4) Stalagmite oxygen isotope record from North Oman (Neff et al., 2001). 


\section{Table Captions}

Table 1. Radiocarbon ages and the corresponding calendar ages for the marine core MD921002.

Table 2.List of pollen and spore taxa determined from the core MD92-1002 in the Gulf of Aden. 

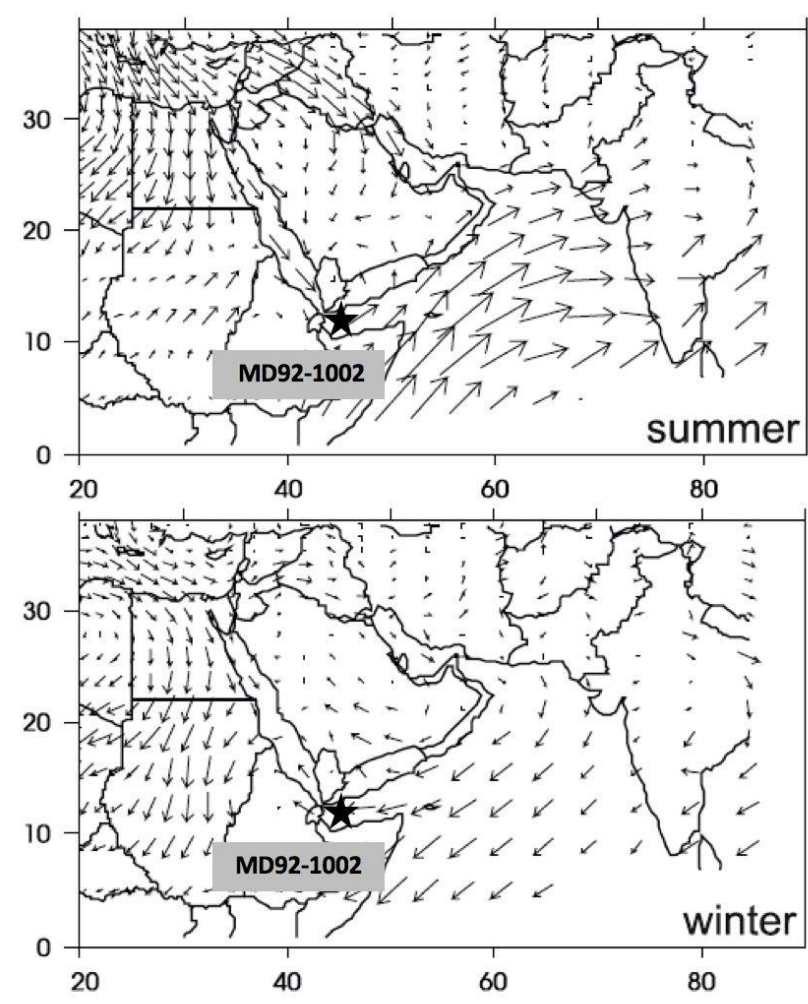

Figure 1 


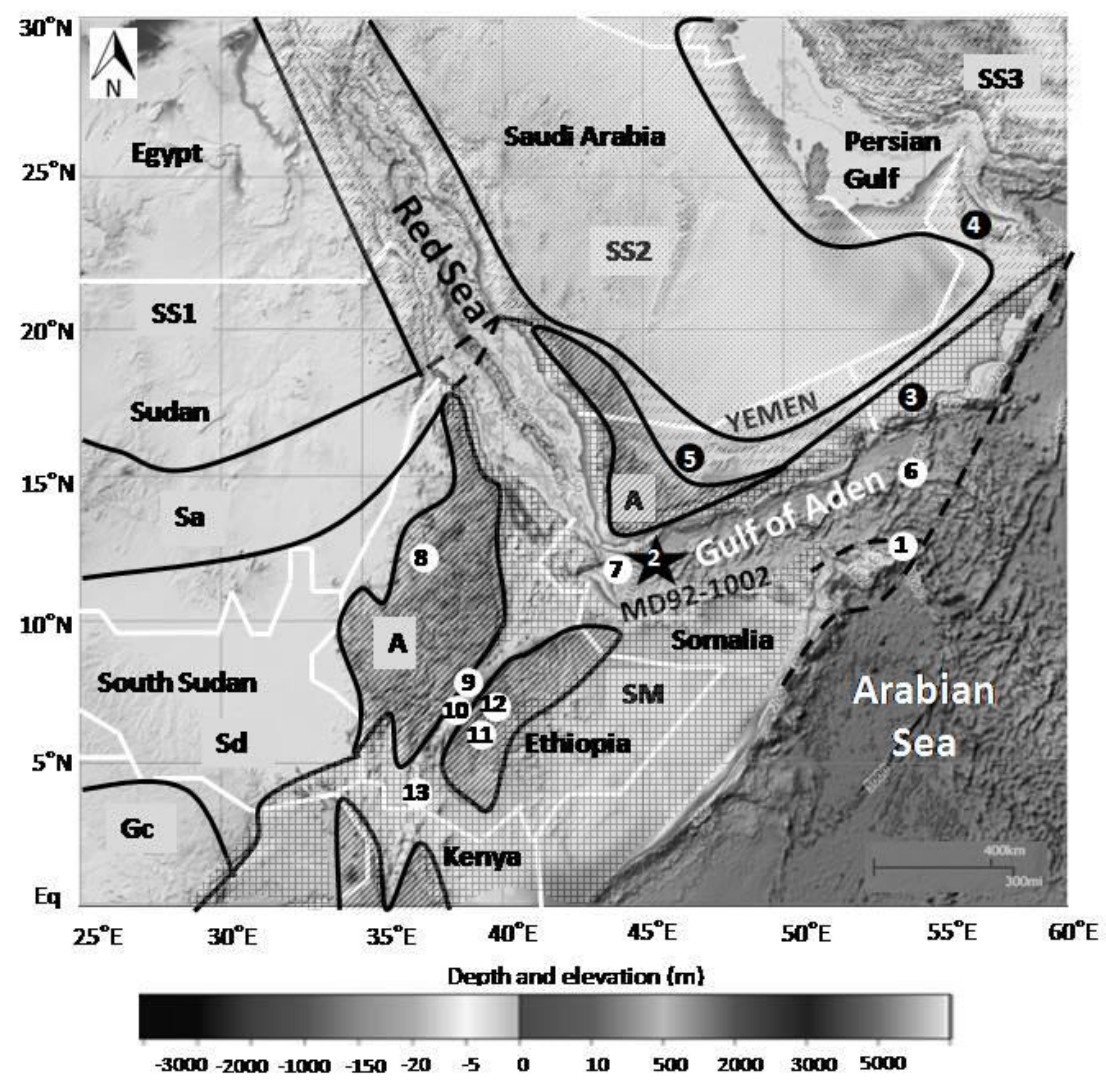

Figure 2 


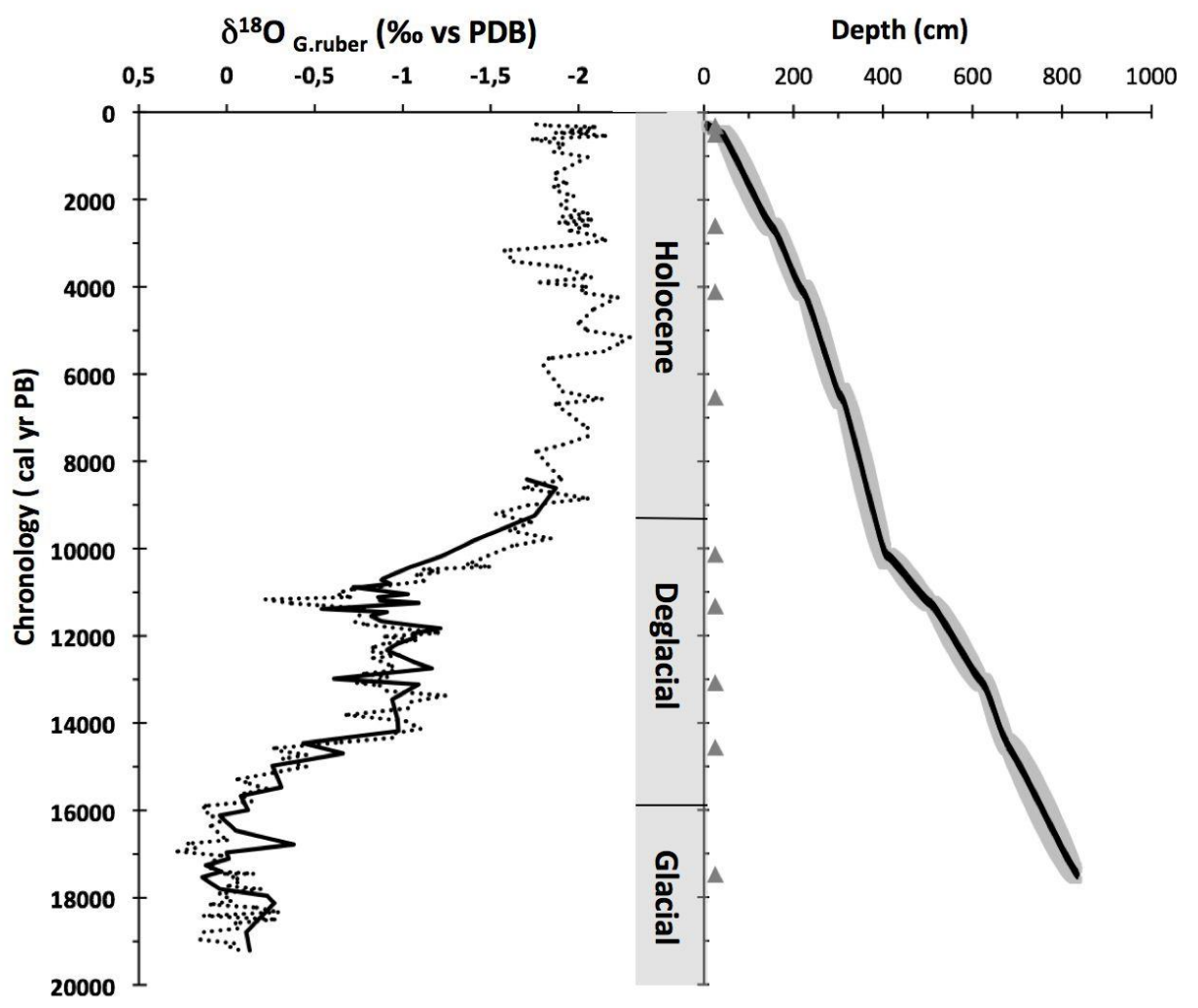

Figure 3 


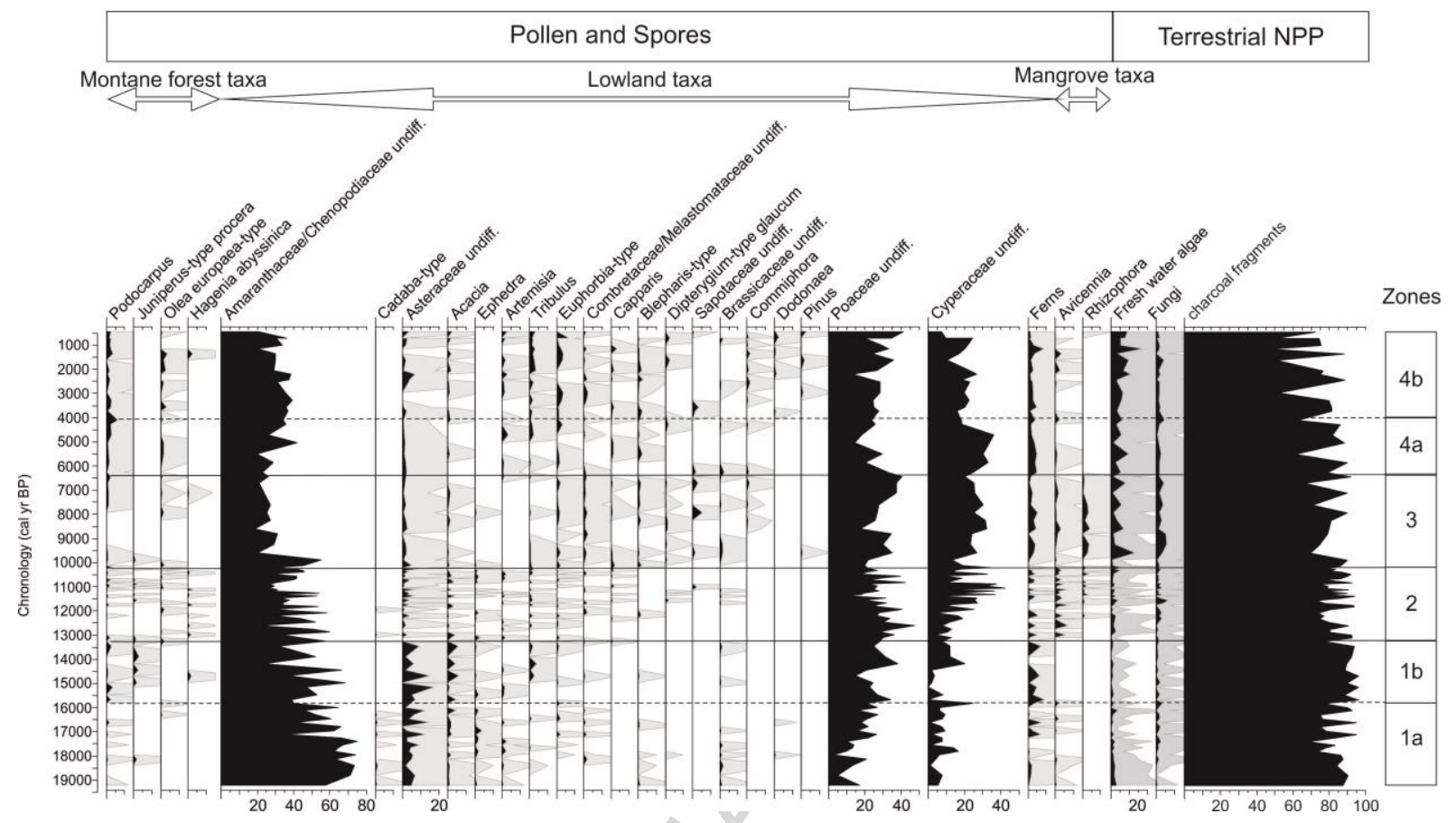

Figure 4 


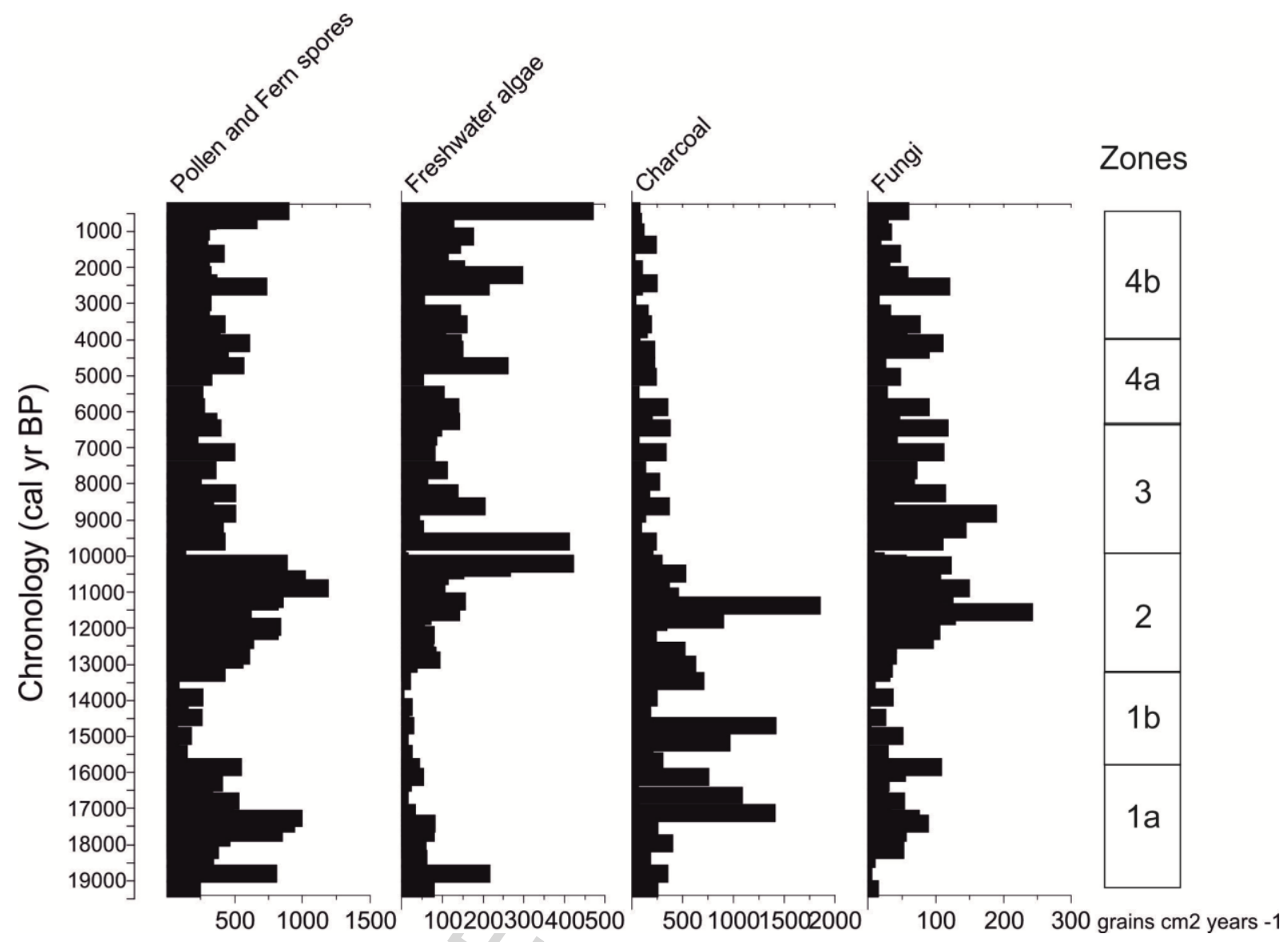

Figure 5 


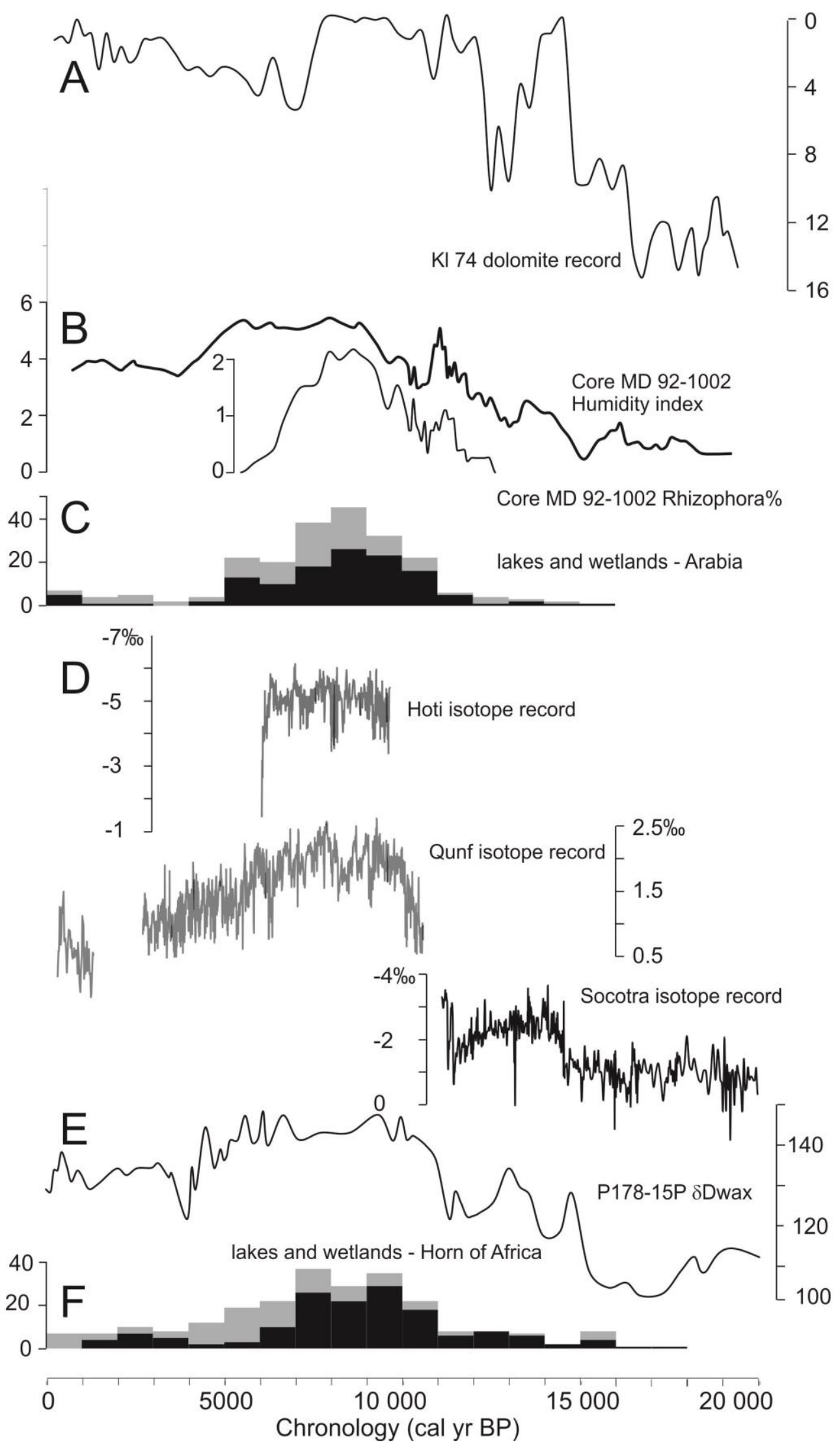

Figure 6 

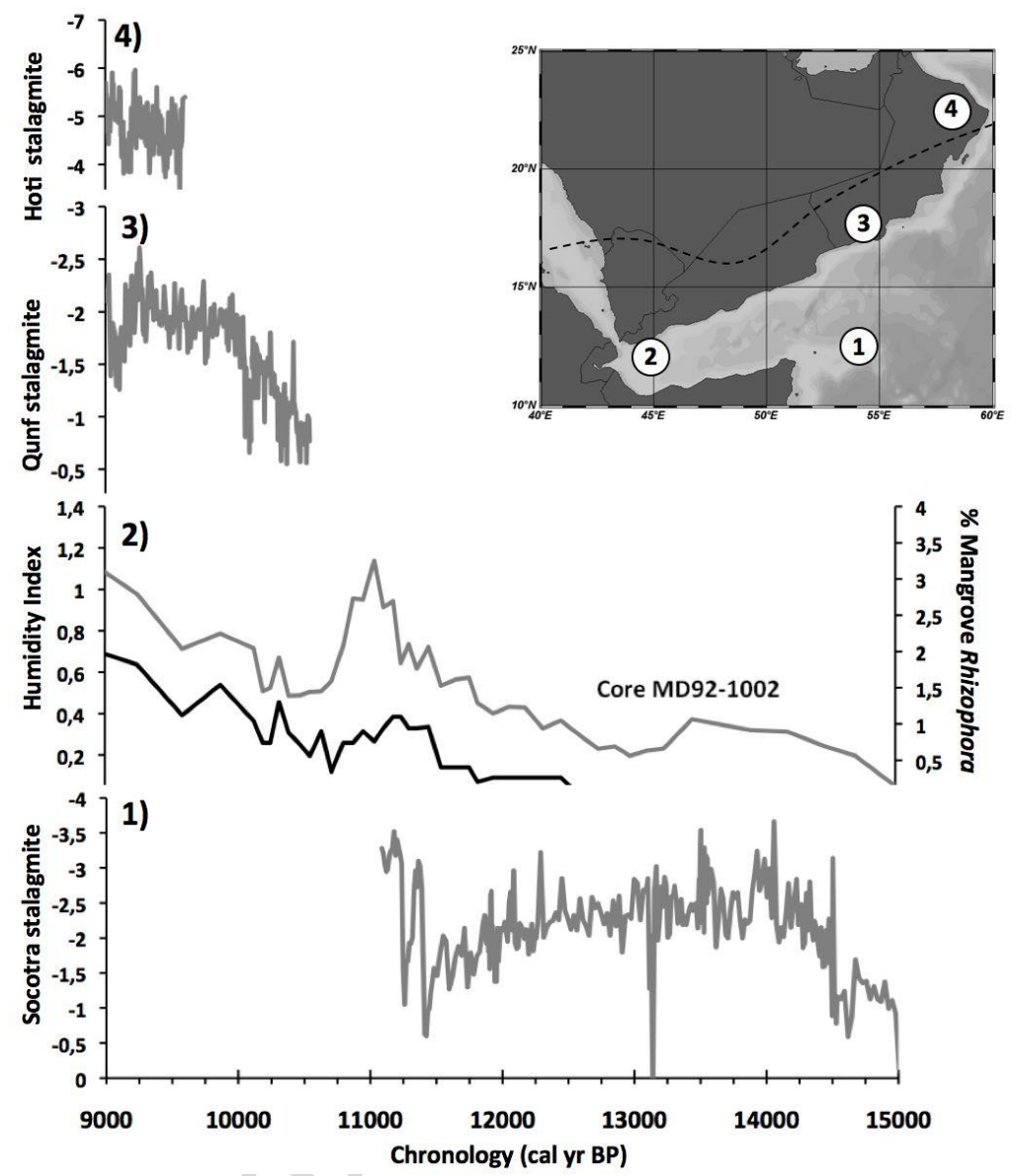

Figure 7 
Table 1

\begin{tabular}{|c|c|c|c|c|}
\hline Depth (cm) & Sample code & Material & $\begin{array}{l}\text { AMS }{ }^{14} \mathrm{C} \text { age }\left({ }^{14} \mathrm{C}\right. \\
\text { yr BP })\end{array}$ & $\begin{array}{l}\text { Oxcal calibrated } \\
\text { age (Cal yr BP) }\end{array}$ \\
\hline 5 & MD92-1002/ I-5 cm & G. ruber & $820 \pm 30$ & $303 \pm 96$ \\
\hline 39.5 & MD92-1002/ I-39.5 cm & G. ruber, G. sacculifer & $1045 \pm 40$ & $498 \pm 75$ \\
\hline 152 & MD92-1002/ II-3 cm & G. ruber & $3015 \pm 30$ & $2594 \pm 105$ \\
\hline 221.5 & MD92-1002/ II-72.5 cm & G. ruber & $4235 \pm 30$ & $4110 \pm 118$ \\
\hline 306.5 & MD92-1002/ III-7.5 cm & G. ruber & $6265 \pm 35$ & $6530 \pm 96$ \\
\hline 407.5 & MD92-1002/ III-108.5 cm & G. ruber & $9475 \pm 40$ & $10135 \pm 121$ \\
\hline 507.5 & MD92-1002/IV-57.75 cm & G. ruber & $10450 \pm 40$ & $11315 \pm 155$ \\
\hline 622.75 & MD92-1002/ V-22.75 cm & & $11760 \pm 45$ & $13074 \pm 108$ \\
\hline 677.5 & MD92-1002/ V-77.5 cm & G. ruber, G. sacculifer & $13000 \pm 50$ & $14558 \pm 233$ \\
\hline 834 & MD92-1002/ VI-84 cm & G. ruber, G. sacculifer & $14910 \pm 60$ & $17474 \pm 148$ \\
\hline
\end{tabular}


Table 2

\begin{tabular}{|c|c|}
\hline Arboreal Pollen & Non-Arboreal Pollen \\
\hline Tropical trees and shrubs & Herbs and undiff. \\
\hline Acacia & Acanthaceae undiff. \\
\hline Acacia ehrenbergiana-type & Aerva-type \\
\hline Acacia tortilis-type & Aizoaceae undiff. \\
\hline Anacardiaceae undiff. & Amaranthaceae/Chenopodiaceae undiff. \\
\hline Blighia & Apiaceae undiff. \\
\hline Cadaba-type & Artemisia \\
\hline Calligonum polygonoides & Asclepiadaceae undiff. \\
\hline Capparis & Asteraceae undiff. \\
\hline Cassipourea & Blepharis-type \\
\hline Commiphora & Brassicaceae undiff. \\
\hline Dodonaea & Capparidaceae undiff. \\
\hline Ephedra & Celosia-type \\
\hline Ericaceae undiff. & Centaurea-type perrottetii \\
\hline Euclea & Cichorieae undiff. \\
\hline Hagenia abyssinica & Cleome-type \\
\hline Hyphaene-type & Combretaceae/Melastomataceae undiff. \\
\hline Juniperus-type 1 & Convolvulacee undiff. \\
\hline Macaranga-type & Convolvulus-type \\
\hline Myrica & Cornulaca \\
\hline Olea europaea-type & Cyperaceae undiff. \\
\hline Podocarpus & Dipterygium-type glaucum \\
\hline Prunus africana-type & Euphorbia-type \\
\hline Rosa abyssinica-type & Fabaceae undiff. \\
\hline Sapindaceae undiff. & Fagonia \\
\hline Sapotaceae undiff. & Hypoestes-type \\
\hline Schefflera abyssinica-type & Lippia-type \\
\hline Tamarix & Mollugo cerviana-type \\
\hline Trichilia-type & Monocotyledoneae undiff. \\
\hline Vitellaria-type paradoxa & Oenanthe-type \\
\hline Xylia-type & Plantago \\
\hline Temperate trees & Poaceae undiff. \\
\hline Pinus & Reseda-type \\
\hline Mangrove trees & Rosaceae undiff. \\
\hline Avicennia marina & Rumex \\
\hline Rhizophora mucronata & Schrankia leptocarpa \\
\hline & Sclerocephalus arabicus \\
\hline
\end{tabular}




\begin{tabular}{|l|l|} 
& Solanum-type \\
Suaeda-type \\
Tribulus \\
Typha \\
Zygophyllum \\
\cline { 2 - 3 } & Spores \\
\cline { 2 - 3 } & Monoletes undiff. \\
Pteridophyta undiff. \\
Triletes undiff.
\end{tabular}




\section{Highlights}

- Holocene Humid Period (HHP) reconstructed from a pollen record in the Gulf of Aden;

- Humidity increased since about $14.9 \mathrm{ka}$ BP and reached a maximum between 9-7.5 ka BP;

- Rhizophora\% and speleothem records reveal NW movement of ITCZ at the HHP onset. 